\title{
Intra-sample, inter-sample and down-core microvariation in sea-surface temperature estimates obtained from planktonic foraminifera in the NE Atlantic
}

\author{
BRIAN M. FUNNELL ${ }^{1} \&$ JANE E. SWALLOW ${ }^{2}$ \\ ${ }^{1}$ School of Environmental Sciences, University of East Anglia, Norwich NR4 7TJ, UK. \\ ${ }^{2}$ Present Address: Department of Palaeontology, The Natural History Museum, Cromwell Road, London SW7 5BD, UK.
}

\begin{abstract}
Quantitative investigation of populations of planktonic foraminifera in core-top and down-core (top $10 \mathrm{~cm}$ ) samples from 14 sites in the NE Atlantic, between $19^{\circ}$ to $52^{\circ} \mathrm{N}$ and $11^{\circ}$ to $30^{\circ} \mathrm{W}$, have revealed no intra-sample, inter-sample or down-core variability beyond that to be expected on counts of 300 specimens ( 2 standard deviations, $95 \%$ confidence interval). Application of F20 transfer function analysis shows that estimates of sea-surface temperature, based on these counts, fall within a range of $\pm 1.9^{\circ} \mathrm{C}$ (precision). However, when these estimates are compared with 'actual' temperatures within the $1^{\circ}$ latitude/longitude squares containing the sites, the estimate errors range as high as $\pm 3.6^{\circ} \mathrm{C}$ (accuracy). These results indicate there is a continuing need to improve methods for estimating proxy temperatures from planktonic foraminifera, in order to match the requirements of numerical modellers of past climates. J. Micropalaeontol. 16(2): 163-174, October 1997
\end{abstract}

\section{INTRODUCTION}

Calibration (or training) sets of core-top assemblage data are crucial for the inference of accurate micropalaeontological proxy-values for past ocean temperatures, salinities, productivities, etc. The first such sets for planktonic foraminifera were assembled in connection with the CLIMAP programme development of Transfer Function Analysis (TFA) (Imbrie \& Kipp, 1971; Imbrie et al., 1973; Kipp, 1976), and additional compilations were prepared in connection with the development of the Modern Analog Technique (MAT) (Prell, 1985). The need for further expansion of such calibration sets has recently been recognized by the establishment of SCOR Working Group 100, and the IMAGES programme of the PAGES core project of IGBP $(S C O R=$ Scientific Committee on Oceanic Research, IMAGES = International Marine Global Environmental Changes, PAGES $=$ Past Global Environmental Changes, IGBP = International Geosphere Biosphere Programme). Meantime several centres, in addition to ourselves, and including Barash (Moscow) and Pflaumann (Kiel), have been independently adding to knowledge of ocean core-top distribution of planktonic foraminiferal assemblages. In 1992 we embarked on a study of the core-top distribution of planktonic foraminifera in a selected area of the NE Atlantic, mainly utilizing the archive of cores at the NERC's Institute of Oceanographic Sciences Deacon Laboratory (Wormley).

As part of our investigation we looked again at the errors inherent in sea-surface temperature (SST) estimates made using a specific TFA, that are due to: (a) intra-sample, (b) intersample, and (c) down-core variations in the percentage abundances of planktonic foraminiferal species. For this purpose we examined planktonic foraminifera from 14 sites, ranging between $19^{\circ}$ and $52^{\circ} \mathrm{N}$ and between $11^{\circ}$ and $30^{\circ} \mathrm{W}$ (Fig. 1). For ease of reference in this paper we have labelled these sites V1-6 (intra-sample and down-core investigation), M1-5 (inter-sample investigation) and T1-3 (trans-turbidite investigation); the original core station numbers, locations and other details are given in Table 1.

For our intra-sample investigation we have taken two subsamples from the same core-top intervals, and subjected them to

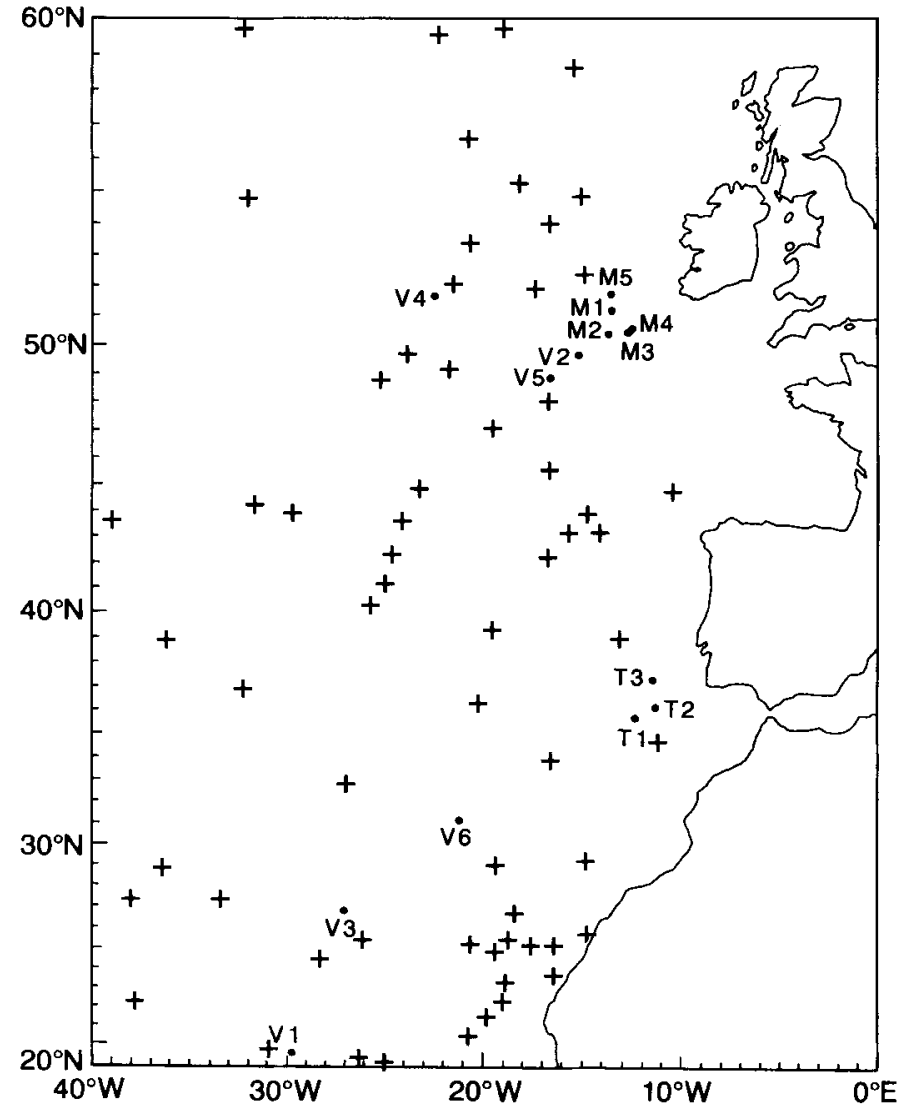

Fig. 1. Lacation of sites $(\bullet)$ studied in this investigation, and location of core-top sites $(+)$ used to generate the calibration data for the F20 Transfer Function (Molfino et al., 1982).

the same preparation and species-counting procedures. Since CLIMAP it has been customary to count (identify) approximately 300 specimens to estimate the percentage abundance of species in the total population. The associated statistical error (2 standard deviations, $95 \%$ confidence interval) on a count of 300 


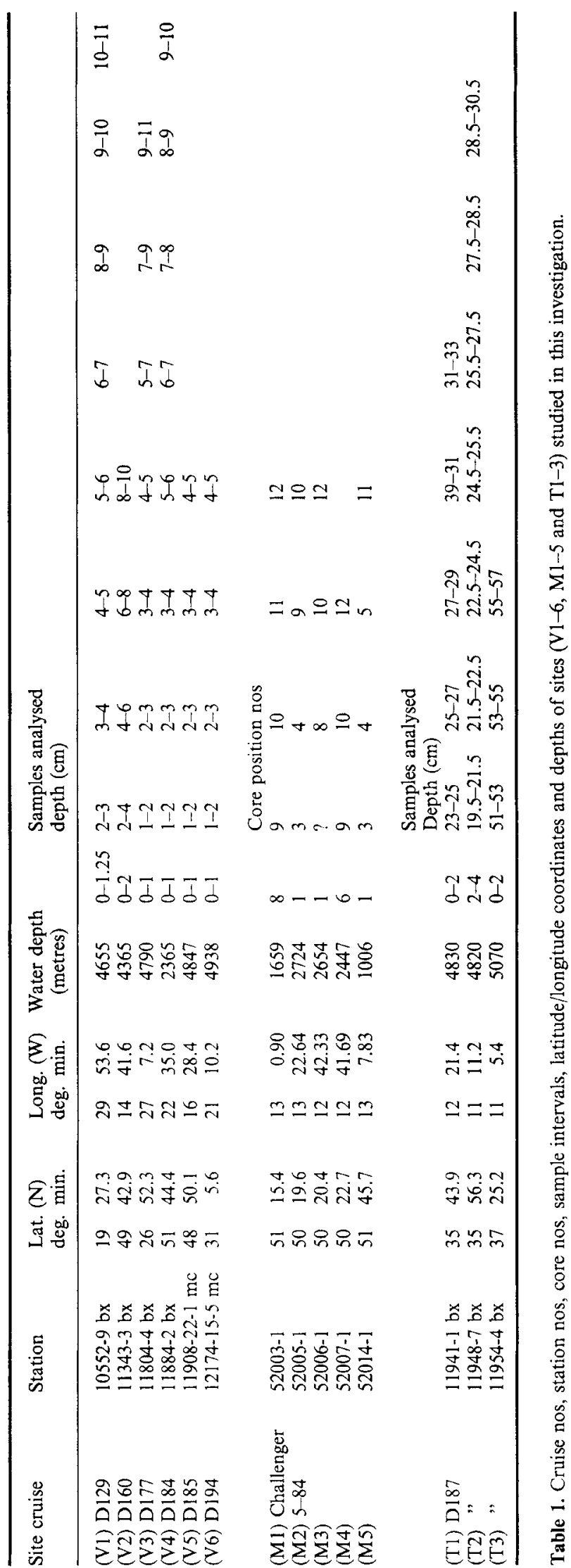


specimens varies from $\pm 5.8 \%$ at $50 \%$ abundance to $\pm 0.7 \%$ at $0.3 \%$ abundance. In practical terms this means that replicate counts of 300 specimens randomly selected from a natural population will yield percentages that fall within the stated statistical error limits 95 times out of 100 . A count of 150/300 $(50 \%)$ could represent an actual percentage in the total population of between 44.2 and $55.8 \%$; a count of $5 / 300$ $(1.7 \%)$ an actual percentage of between 0.1 and $2.9 \%$; and a count of $1 / 300(0.3 \%)$ an actual percentage of between 0.0 and $1.0 \%$ ).] The results of our counting of duplicate core-top samples from cores V1 to V6 are given in Table 2.

For our inter-sample investigation we have taken samples from Multi-corer core-tops. Multi-corers take 12 separate cores within a $1 \mathrm{~m}$ radius. Therefore they sample any microvariation in the lateral distribution of microfossils at and near the sea-bed surface at a $<2 \mathrm{~m}$ scale. Gooday \& Lambshead (1989) have reported on results for benthic foraminifera. As far as we know ours is the first investigation of the microdistribution of planktonic foraminifera in sea-bed sediments. The same preparation and species-counting procedures were used as for the intra-sample investigation. The results of our counting of multiple core-top samples from Multi-corer deployments M1 to M5 are given in Table 3 .

For our down-core investigation we have taken samples from successive 1 or $2 \mathrm{~cm}$ intervals down to $10 \mathrm{~cm} \mathrm{depth,} \mathrm{and}$ subjected them to the same preparation and counting procedures as the intra- and inter-sample samples. In most deep-sea cores this $10 \mathrm{~cm}$ zone is likely to be one of active, present-day bioturbation, and the contained microfossils therefore represent the climatic equivalent of the latest Holocene, rather than solely the present-day. Consequently little change in the planktonic foraminiferal assemblages over this interval is to be expected. On the other hand confirmation of this expectation would indicate that samples taken from cores whose top few centimetres are unsampleable, or have been lost on collection, may still be useful contributors to a calibration set. Some 'coretop' samples used in the CLIMAP calibration set were obtained from $10 \mathrm{~cm}$ depth. The results of our counting of down-core samples are given in Table 4.

In addition to our study of intra-sample, inter-sample and down-core variation we also made trans-turbidite comparisons on three cores where core-top samples were immediately underlain by turbidites, and could be directly compared with the sub-turbidite assemblages. (The supra-turbidite samples in these cases would not have been able to develop mixing by bioturbation with the underlying earlier Holocene pelagic sediment.)

\section{METHODS}

The Box-corer subcores and Multi-corer cores used in the intrasample and down-core investigations, (V1-6 of this paper), were obtained during various cruises of RRS Discovery. Full details of the Cruise and Core numbers and Station data are given in Table 1. The Box-corer subcores had been previously sectioned and used for pore-water analysis, and the samples taken for the present investigation were obtained from the remaining 'squeezed' cakes. (The samples obtained from this source proved to contain relatively low percentages of fragmented planktonic foraminifera, indicating that the prior processing of the samples had not damaged the planktonic foraminifera.) The Multi-corer cores had also been previously sectioned, but the resultant core slices were preserved in buffered (neutral) formaline or alcohol.

The Multi-corer cores used in the inter-sample investigation (M1-M5 of this paper), were obtained by RRS Challenger (Table 1).

The Box-corer cores, used for the trans-turbidite investigation (T1-3 of this paper), were obtained by RRS Discovery (Table 1).

All samples from both Box-corer and Multi-corer sources were oven-dried to disaggregate the sediment, then washed through a $63 \mu \mathrm{m}$ sieve. The $>63 \mu \mathrm{m}$ fraction was dry-sieved to separate the $>150 \mu \mathrm{m}$ and the $150-63 \mu \mathrm{m}$ fractions.

The $>150 \mu \mathrm{m}$ fractions were sub-divided, using a random sediment splitter to ensure equal division of larger and smaller planktonic foraminifera, in order to obtain sub-samples containing approximately 300 whole specimens. The planktonic foraminifera were identified (Plate 1) in accordance with the standard taxonomy used in connection with the F20 transfer function (Molfino et al., 1982), and the planktonic/benthic ratio determined at the same time. The number of fragments of planktonic foraminifera encountered while counting $c .300$ whole planktonic foraminifera was also recorded. All results are set out in Tables 2-4.

\section{RESULTS}

Twenty-eight species of planktonic foraminifera, including the Neogloboquadrina pachyderma (dextral)/dutertrei intergrade form (Kipp, 1976), were identified and percentage abundances calculated. Coiling direction, colour and form of species were also distinguished wherever appropriate. Percentage benthic foraminifera, and percentage planktonic foraminiferal fragments were separately determined relative to the total count (c.300) of whole planktonic foraminifera. All results are set out in Tables 2-4.

All the intra-sample and inter-sample sample sets, and almost all the down-core and trans-turbidite sample sets show no variation between counts obtained on individual cores exceeding that which would be expected from statistical counting error (at the 2 standard deviations, $95 \%$ confidence interval level). This result is at the same time both encouraging (because it implies minimal variability arising from intra-sample, inter-sample, down-core and trans-turbidite variations in the original populations), and disappointing (because it reveals no such variations and leaves statistical counting errors as probably the principal source of lack of precision in TFA estimates of SST).

In the following account we use the terms precision to refer to the consistency of TFA estimates of SST obtained from single sample sets (i.e. from one site), and accuracy to refer to the consistency between TFA-estimated SST values and 'actual' present day SST in the same $1^{\circ}$ latitude/longitude squares. The 'actual' present day SST values we have used are from Levitus (1982).

To evaluate the effects of statistical counting errors on TFA estimates of SST, we have applied the F20 transfer function to all our data. The F20 transfer function (Molfino et al., 1982) is a late version of the type of transfer function originally developed and used for the CLIMAP programme.

Imbrie et al. (1973) had noted that the estimate precision of the earlier $F 3$ transfer function varied according to geographical 
సं

울

is 号

年察

J $\frac{0}{9}$

鲻

뜬

D

ธं 웅

टิं

黄离

通

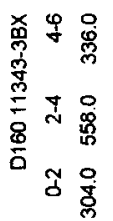

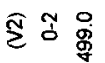

훙옹

응 웅

क

iิ :

号量

筞 总

중 放융

获

응

ó

눙

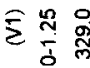

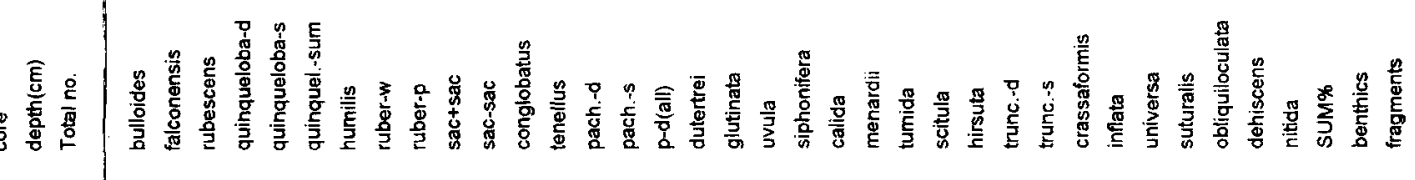

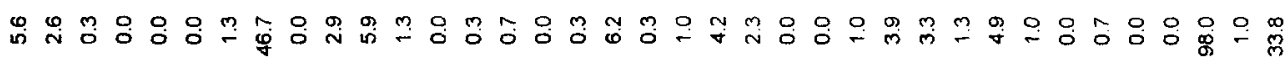

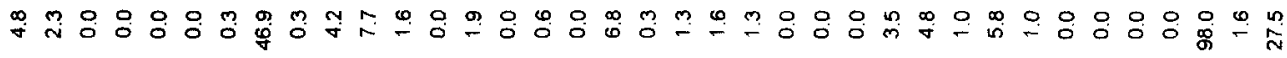

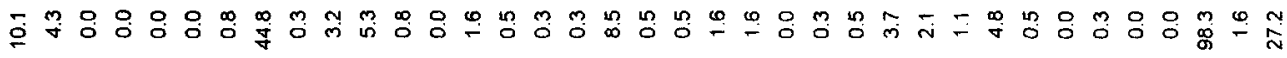

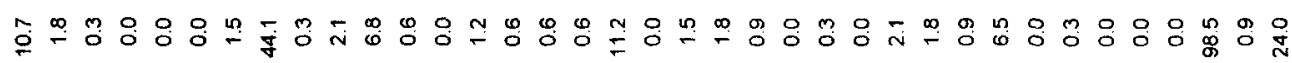

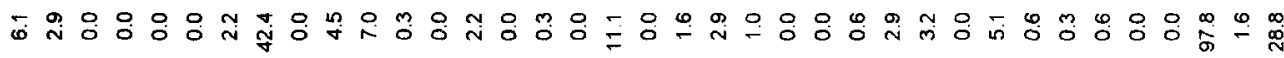

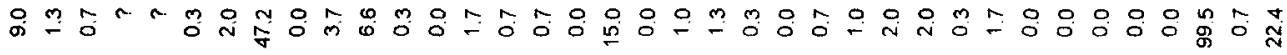

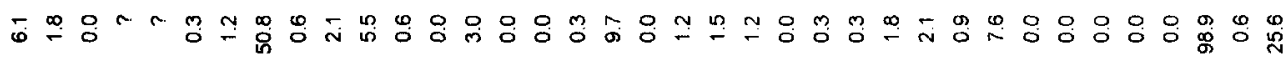

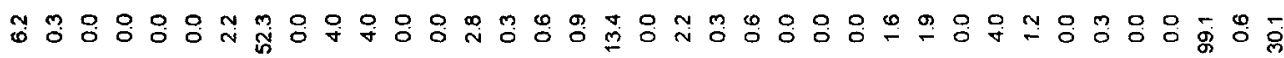

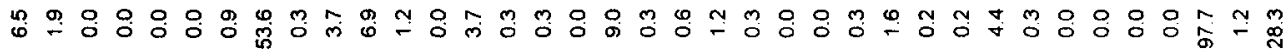

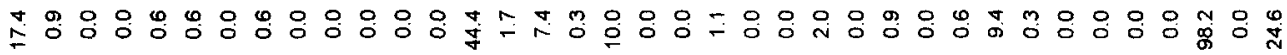

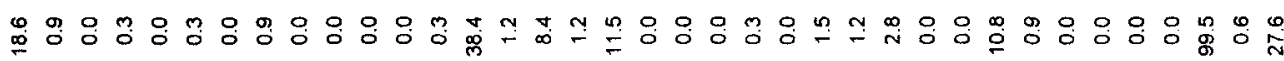

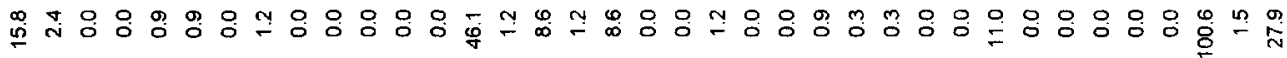

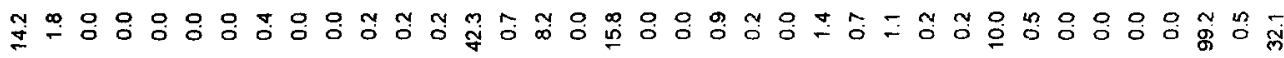

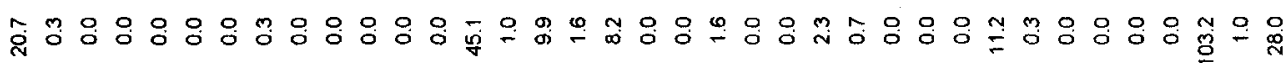

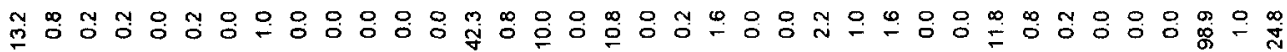

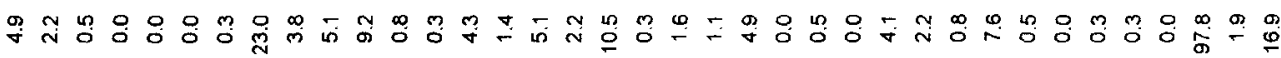
先

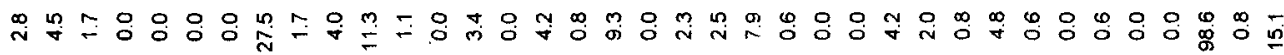

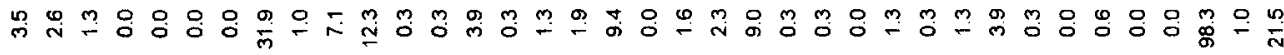

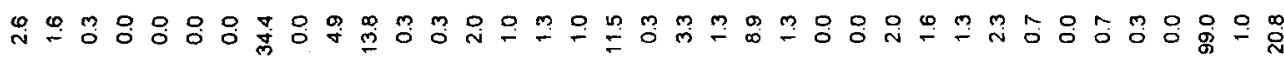

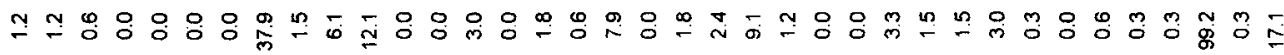

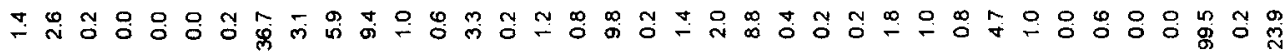

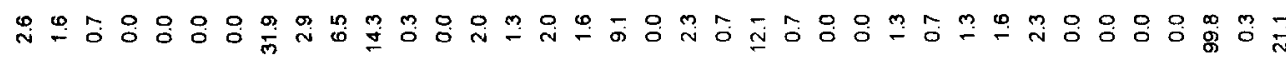

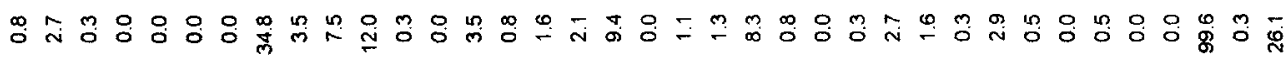

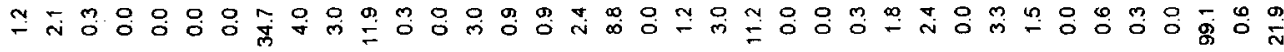




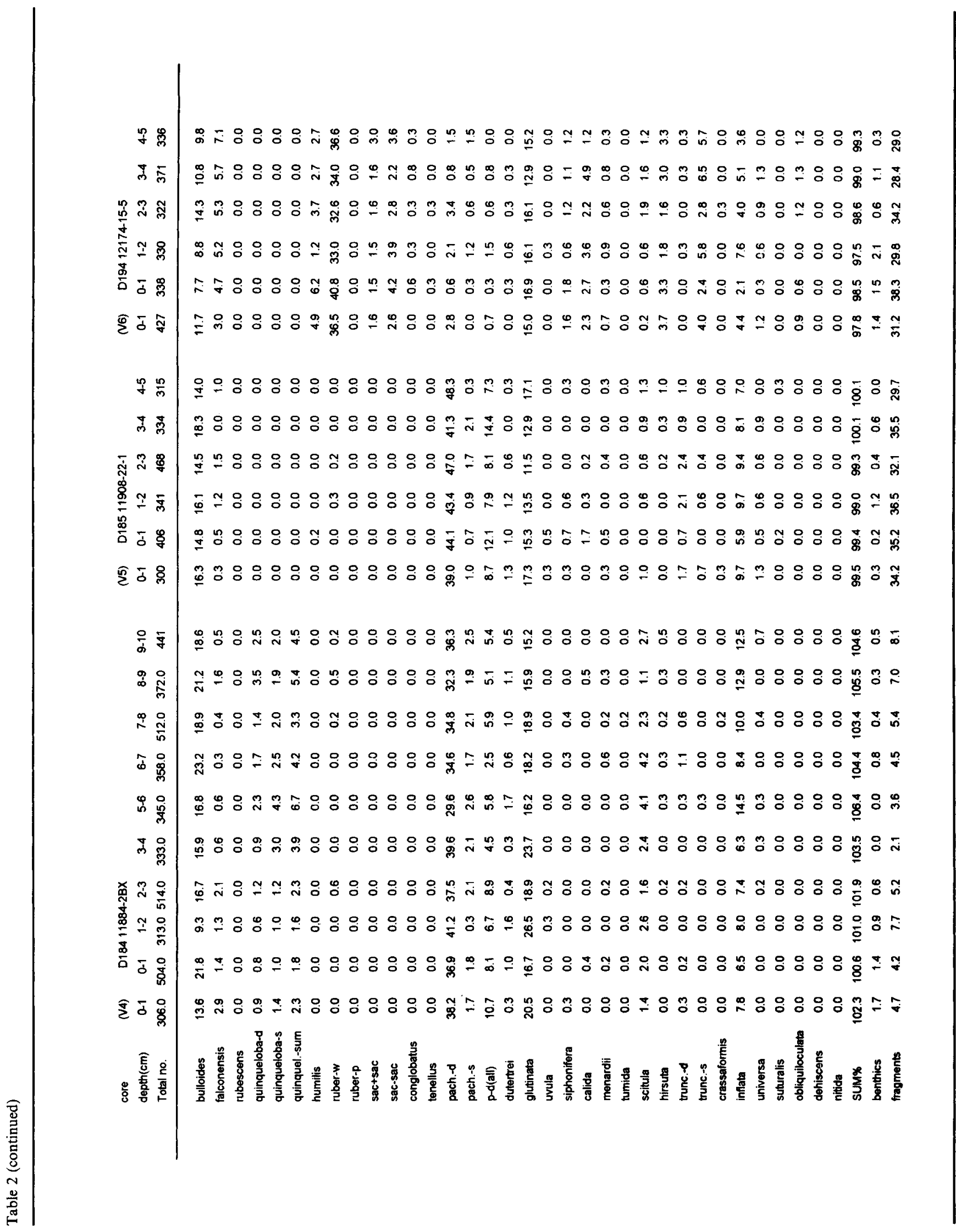




\begin{tabular}{|c|c|}
\hline$=\overline{\bar{n}}$ & 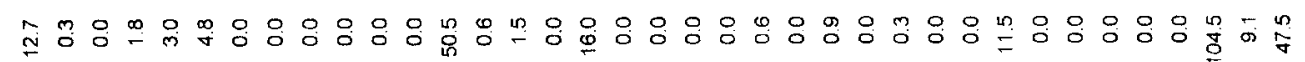 \\
\hline ๙ & 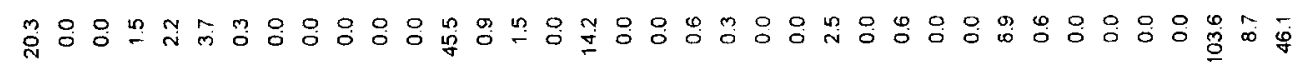 \\
\hline$\checkmark \stackrel{\sim}{\mathbb{M}^{\circ}}$ & 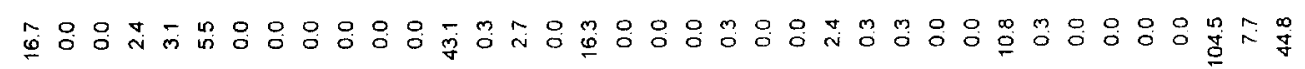 \\
\hline 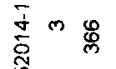 & 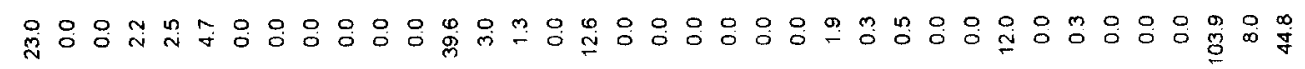 \\
\hline 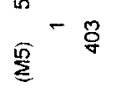 & 巨舟品品 N \\
\hline 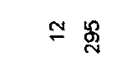 & 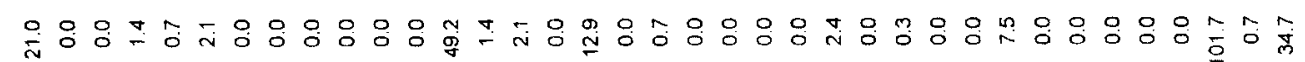 \\
\hline 오 స్ำ & 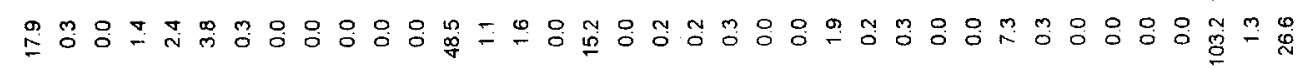 \\
\hline 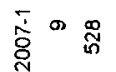 & 点 \\
\hline 胥赵 & 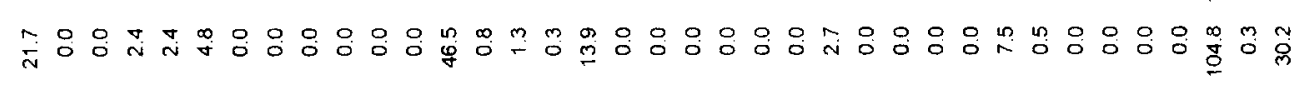 \\
\hline$\simeq \stackrel{\mathscr{B}}{0}$ & 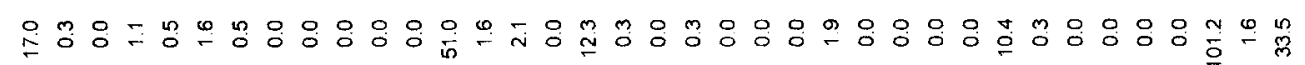 \\
\hline 요 ⿷匚 & 윰ㅇㅇㅇ용 \\
\hline$\infty \stackrel{\infty}{\infty}$ & 귱: $:$ \\
\hline 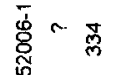 & 응ㅇㅇㅇ용영: \\
\hline 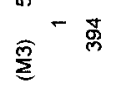 & 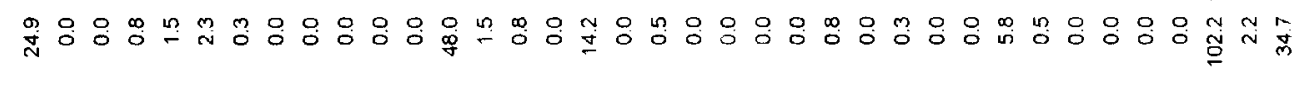 \\
\hline 유용 & 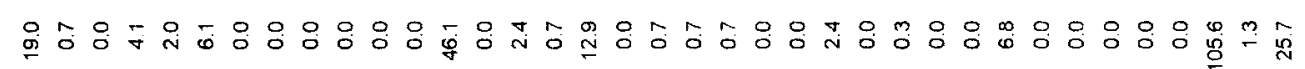 \\
\hline$\stackrel{\infty}{\sigma}$ & 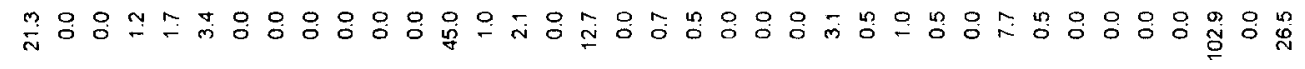 \\
\hline$-\nabla \stackrel{\infty}{\infty}$ & 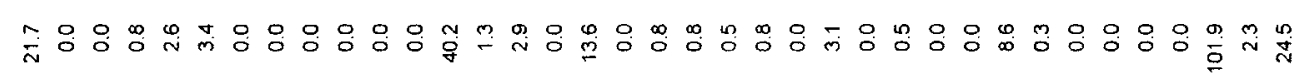 \\
\hline 它 & 质 \\
\hline$\widehat{\mathbb{N}}-\stackrel{\infty}{\underset{\nabla}{*}}$ & 荲品 \\
\hline$\approx$ 嘿 & $\stackrel{n}{N}$ \\
\hline$=\mathscr{g}$ & 谓: \\
\hline$\div$ ํำ & 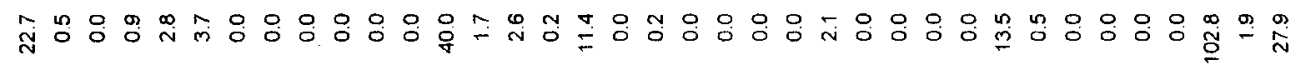 \\
\hline 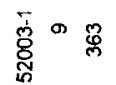 & 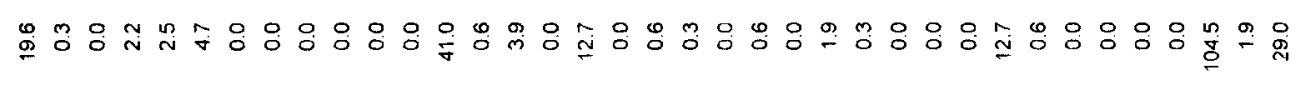 \\
\hline$\widehat{\bar{E}}^{\infty} \stackrel{\infty}{\tilde{m}}$ & 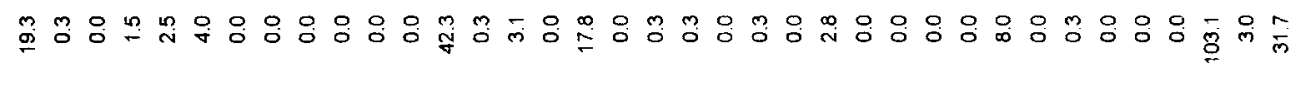 \\
\hline 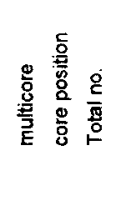 & 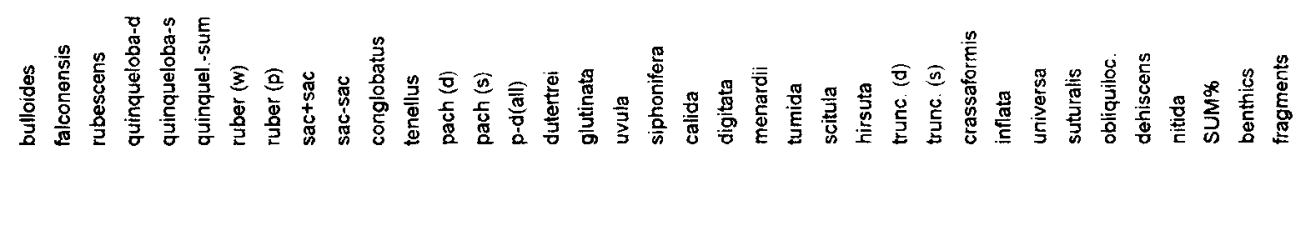 \\
\hline
\end{tabular}



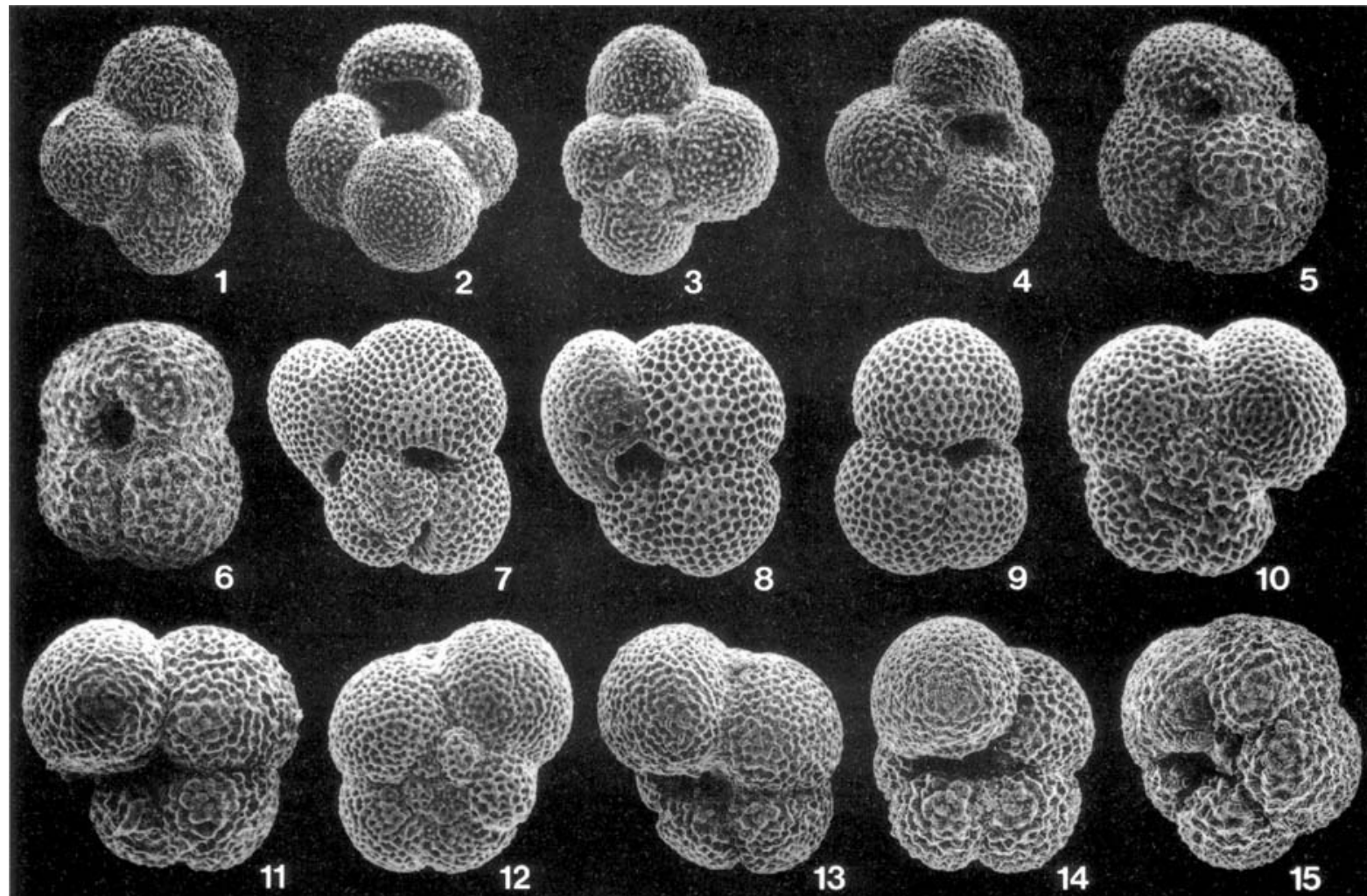

15

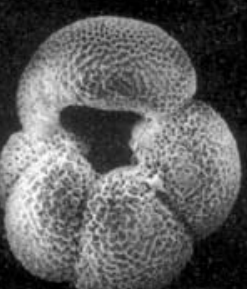

18
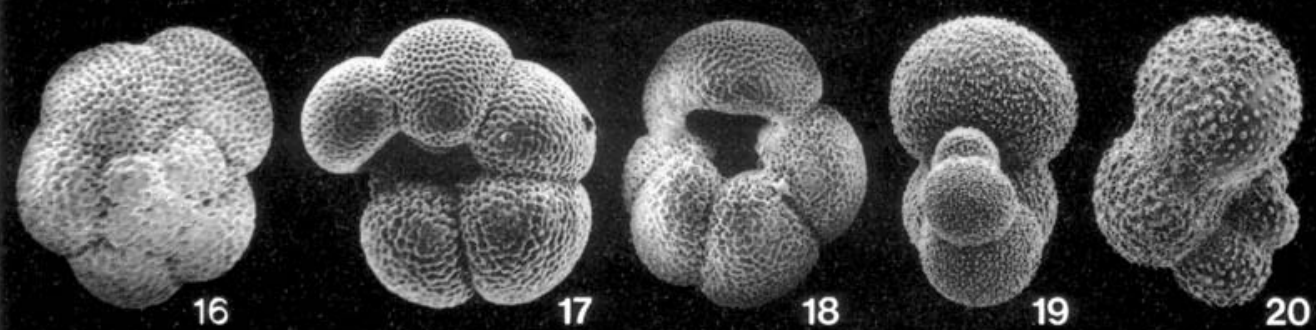

16
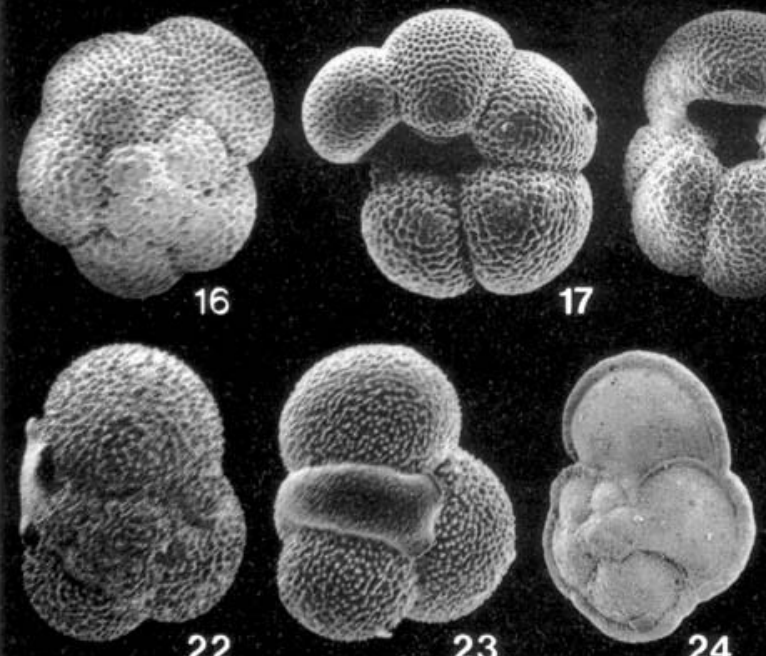

24

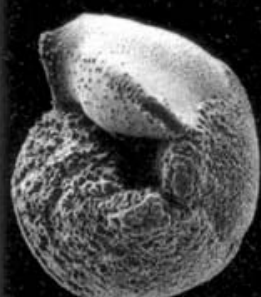

28
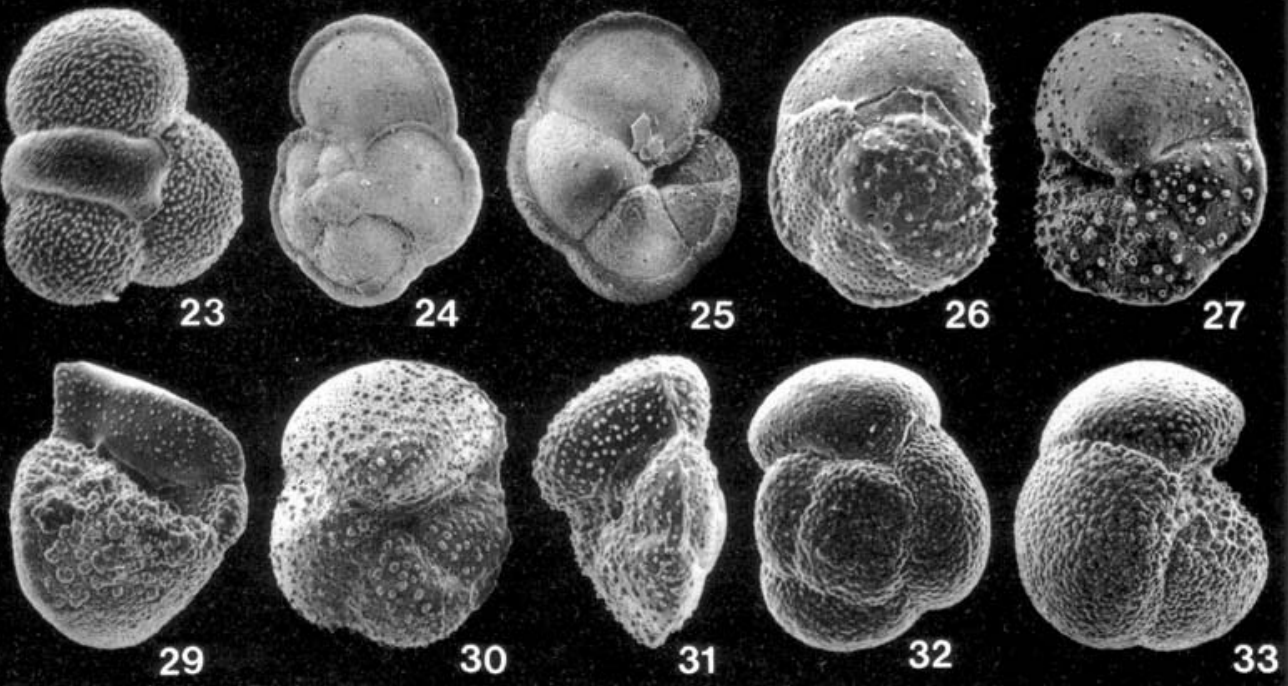


\begin{tabular}{|c|c|c|c|c|c|}
\hline & Core & Depth $(\mathrm{cm})$ & $\mathrm{SST}_{\text {warm }}$ & $\mathrm{SST}_{\text {cold }}$ & Comm. \\
\hline $\begin{array}{l}(4655 \mathrm{~m}) \\
\text { mean } \\
\text { range/2 } \\
\mathrm{SD} \\
\text { 'actual' }\end{array}$ & V1 & $\begin{array}{l}0-1.25 \\
0-1.25\end{array}$ & $\begin{array}{r}26.21 \\
25.77 \\
25.99 \\
0.22 \\
0.31 \\
24.10\end{array}$ & $\begin{array}{r}22.46 \\
22.49 \\
22.48 \\
0.01 \\
0.02 \\
21.70\end{array}$ & $\begin{array}{l}0.95 \\
0.97 \\
0.96\end{array}$ \\
\hline $\begin{array}{l}(4365 \mathrm{~m}) \\
\text { mean } \\
\text { range/2 } \\
\mathrm{SD} \\
\text { 'actual' }\end{array}$ & V2 & $\begin{array}{l}0-2 \\
0-2\end{array}$ & $\begin{array}{r}15.81 \\
14.99 \\
15.40 \\
0.41 \\
0.58 \\
16.80\end{array}$ & $\begin{array}{r}11.39 \\
9.99 \\
10.69 \\
0.70 \\
0.99 \\
13.10\end{array}$ & $\begin{array}{l}0.78 \\
0.78 \\
0.78\end{array}$ \\
\hline $\begin{array}{l}(4790 \mathrm{~m}) \\
\text { mean } \\
\text { range/2 } \\
\mathrm{SD} \\
\text { 'actual' }\end{array}$ & V3 & $\begin{array}{l}0-1 \\
0-1\end{array}$ & $\begin{array}{r}26.00 \\
26.00 \\
26.00 \\
0.00 \\
0.00 \\
22.50\end{array}$ & $\begin{array}{r}20.83 \\
21.08 \\
20.96 \\
0.13 \\
0.18 \\
20.40\end{array}$ & $\begin{array}{l}0.95 \\
0.95 \\
\mathbf{0 . 9 5}\end{array}$ \\
\hline $\begin{array}{l}(2365 \mathrm{~m}) \\
\text { mean } \\
\text { range/2 } \\
\mathrm{SD} \\
\text { 'actual' }\end{array}$ & V4 & $\begin{array}{l}0-1 \\
0-1\end{array}$ & $\begin{array}{r}14.50 \\
13.54 \\
14.02 \\
0.48 \\
0.68 \\
15.00\end{array}$ & $\begin{array}{r}10.57 \\
9.19 \\
9.88 \\
0.69 \\
0.98 \\
12.80\end{array}$ & $\begin{array}{l}0.80 \\
0.83 \\
\mathbf{0 . 8 2}\end{array}$ \\
\hline $\begin{array}{l}(4847 \mathrm{~m}) \\
\text { mean } \\
\text { range/2 } \\
\mathrm{SD} \\
\text { 'actual' }\end{array}$ & V5 & $\begin{array}{l}0-1 \\
0-1\end{array}$ & $\begin{array}{r}15.22 \\
14.08 \\
14.65 \\
0.57 \\
0.81 \\
18.20\end{array}$ & $\begin{array}{r}10.67 \\
10.42 \\
10.55 \\
0.13 \\
0.18 \\
13.10\end{array}$ & $\begin{array}{l}0.80 \\
0.79 \\
\mathbf{0 . 8 0}\end{array}$ \\
\hline $\begin{array}{l}(4938 \mathrm{~m}) \\
\text { mean } \\
\text { range/2 } \\
\mathrm{SD} \\
\text { 'actual' }\end{array}$ & V6 & $\begin{array}{l}0-1 \\
0-1\end{array}$ & $\begin{array}{r}25.81 \\
26.56 \\
\mathbf{2 6 . 1 9} \\
0.38 \\
0.53 \\
23.30\end{array}$ & $\begin{array}{r}18.87 \\
19.91 \\
19.39 \\
0.52 \\
0.74 \\
18.60\end{array}$ & $\begin{array}{l}0.95 \\
0.95 \\
0.95\end{array}$ \\
\hline
\end{tabular}

Table 5A. Results of F20 TFA of core-top samples from sites V1-6.

\begin{tabular}{|c|c|c|c|c|c|c|c|}
\hline \multirow[b]{2}{*}{ Core } & \multicolumn{3}{|c|}{ Precision } & \multicolumn{4}{|c|}{ Accuracy } \\
\hline & $\begin{array}{l}\mathrm{SST}_{\text {warm }} \\
\text { range } / 2\end{array}$ & $\mathrm{SD}$ & $\begin{array}{l}\mathrm{SST}_{\text {cold }} \\
\text { range } / 2\end{array}$ & $\mathrm{SD}$ & $\mathrm{SST}_{\text {warm }}$ & $\mathrm{SST}_{\text {cold }}$ & Comm. \\
\hline V1 & 0,22 & 0.31 & 0.01 & 0.02 & 1.89 & 0.78 & 0.96 \\
\hline V2 & 0.41 & 0.58 & 0.7 & 0.99 & -1.4 & -2.41 & 0.78 \\
\hline V3 & 0 & 0 & 0.13 & 0.18 & 3.5 & 0.56 & 0.95 \\
\hline V4 & 0.48 & 0.68 & 0.69 & 0.98 & -0.98 & -2.92 & 0.82 \\
\hline V5 & 0.57 & 0.81 & 0.13 & 0.18 & -3.55 & -2.55 & 0.8 \\
\hline V6 & 0.38 & 0.53 & 0.52 & 0.74 & 2.89 & 0.79 & 0.95 \\
\hline $\min$. & 0 & & 0.01 & & -3.55 & -2.92 & \\
\hline $\max$ & 0.51 & & 0.7 & & 3.5 & 0.79 & \\
\hline
\end{tabular}

Table 5B. Comparison of core-top F20 SST estimates with 'actual' SST at sites V1-6. location as the transfer function was applied to faunas with different community structures. With the F3 transfer function mid-latitude samples tended to have lower precision, whereas single assemblage samples, e.g. polar, had higher precision. Imbrie et al. (1973) measured sample precision using five replicate samples. Their highest precision was $\pm 0.40-0.54^{\circ} \mathrm{C}$ (range $0.80-1.07^{\circ} \mathrm{C}$ ) and lowest $\pm 2.00^{\circ} \mathrm{C}$ (range $4.00^{\circ} \mathrm{C}$ ). Molfino et al. (1982) assessed the accuracy limits of the F20 transfer function as $\pm 1.2^{\circ} \mathrm{C}$ (range $2.4^{\circ} \mathrm{C}$ ) for SST-warm (i.e. summer) estimates.

The likely reliability of TFA estimates of SST can also be evaluated by calculating a communality value for each sample. This measures the similarity of the planktonic foraminiferal assemblages under investigation to those used in the original calibration set used to generate the transfer function (Imbrie \& Kipp, 1971). A communality value of 1 indicates that the calibration and investigated assemblages are identical. Imbrie $e t$ al. (1973) considered that values $>0.8$ indicated that the assemblages under investigation fell significantly within the range of the assemblages used to calibrate the transfer function. In our results (Tables 5B-8) communality values range between 0.69 and 0.97 . Seventy per cent of our results have communality values $>0.8$. The lower communality values $(0.63-0.78)$ all relate to samples (M1-5) from the Porcupine Sea Bight where smaller percentages of the pachyderma (d)/dutertrei intergrades are recorded by us, compared with those mapped by Kipp (1976) from the same general area.

\section{DISCUSSION}

Our intra-sample variability results, expressed in terms of F20 $\mathrm{SST}_{\text {warm }}$ (= summer) and $\mathrm{SST}_{\text {cold }}$ (= winter) estimates, are summarized in Table 5A, and the precision and accuracy of these estimates are compared in Table $5 \mathrm{~B}$. The minimum range of the $\mathrm{SST}_{\text {warm }}$ estimates is $\pm 0.0^{\circ} \mathrm{C}$ and the maximum $\pm 0.51^{\circ} \mathrm{C}$; for $\mathrm{SST}_{\text {cold }}$ the comparable figures are $\pm 0.01^{\circ} \mathrm{C}$ and $\pm 0.70^{\circ} \mathrm{C}$, respectively. However, when we come to compare these estimates with the 'actual' present-day sea-surface temperatures in the relevant $1^{\circ}$ latitude/longitude square, we find much larger discrepancies. SST $_{\text {warm }}$ estimates range from an underestimate of $-3.55^{\circ} \mathrm{C}$ to an overestimate of $+3.5^{\circ} \mathrm{C}$, whereas $\mathrm{SST}_{\text {cold }}$ estimates range from an underestimate of $-2.92^{\circ} \mathrm{C}$ to an overestimate of $0.79^{\circ} \mathrm{C}$ (based on the mean, not the extreme, estimate values). The range of variation in the accuracy of these results is considerably larger than the variation in the precision.

Our inter-sample variability results, are summarized in Table $6 \mathrm{~A}$, and the precision and accuracy of these estimates are

\section{Explanation of Plate 1.}

Figs 1-2, Globigerina bulloides: 1, spiral view, $\times 192 ; 2$, umbilical view, $\times 75$. figs 3-4, Globigerina falconensis: 3, spiral view, $\times 196 ; 4$, umbilical view, $\times 204$. figs 5-6, Globigerinoides ruber: 5, spiral view, $\times 184 ; 6$, umbilical view, $\times 225$. figs 7-8, Globigerinoides sacculifer (with sac-like final chamber): 7 , spiral view, $\times 122 ; 8$, umbilical view, $\times 163$. fig. 9, Globigerinoides sacculifer (without sac-like final chamber), umbilical, $\times 143$. figs $10-11$, Neogloboquadrina pachyderma (right coiling): 10, spiral view, $\times 254 ; 11$, umbilical view, $\times 258$. figs $12-15$, Neogloboquadrina pachyderma (right coiling)/Neogloboquadrina dutertrei intergrade: 12 , spiral view, $\times 225 ; 13$, umbilical view, $\times 225 ; 14$, umbilical view, $\times 245,15$, umbilical view, $\times 245$. figs 16-18, Neogloboquadrina dutertrei: 16, spiral view, $\times 113 ; 17$, umbilical view, $\times 125 ; 18$, umbilical view, $\times 102$. fig. 19, Globigerinella siphonifera: edge view, $\times 89$. figs 20-21, Globigerinella calida: 20, umbilical view, $\times 176 ; 21$, edge view, $\times 179$. figs 22-23, Globigerinita glutinata: 22 , spiral view, $\times 225 ; 23$, umbilical view, $\times 187$. figs $24-25$, Globorotalia menardii: 24 , spiral view, $\times 48 ; 25$, umbilical view, $\times 72$. figs $26-27$, Globorotalia hirsuta: 26 spiral view, $\times 220 ; 27$, umbilical view, $\times 217$. figs $28-29$, Globorotalia truncatulinoides (right coiling): 28 , umbilical view, $\times 90 ; 29$, edge view $\times 85$. figs 30-31, Globorotalia crassaformis: 30, umbilical view, $\times 180 ; 31$, edge view, $\times 173$. figs 32-33, Globorotalia inflata: 32, spiral view, $\times 106 ; 33$, umbilical view, $\times 136$. 
Funnell \& Swallow

\begin{tabular}{|c|c|c|c|c|c|}
\hline & Core & m-core & $\mathrm{SST}_{\text {warm }}$ & $\mathrm{SST}_{\text {cold }}$ & Comm. \\
\hline \multirow[t]{5}{*}{$(1659 \mathrm{~m})$} & M1 & 8 & 14.20 & 10.05 & 0.73 \\
\hline & & 9 & 15.20 & 10.19 & 0.75 \\
\hline & & 10 & 14.92 & 9.64 & 0.75 \\
\hline & & 11 & 14.12 & 9.35 & 0.79 \\
\hline & & 12 & 13.81 & 9.36 & 0.74 \\
\hline mean & & & 14.45 & 9.72 & 0.75 \\
\hline range $/ 2$ & & & 0.69 & 0.42 & \\
\hline SD & & & 0.58 & 0.49 & \\
\hline 'actual' & & & 15.70 & 10.20 & \\
\hline \multirow[t]{4}{*}{$(2724 m)$} & M2 & 1 & 13.96 & 9.54 & 0.68 \\
\hline & & 3 & 14.12 & 9.50 & 0.74 \\
\hline & & 9 & 13.88 & 9.49 & 0.70 \\
\hline & & 10 & 14.00 & 9.84 & 0.69 \\
\hline mean & & & 14.02 & 9.56 & 0.71 \\
\hline range $/ 2$ & & & 0.14 & 0.20 & \\
\hline & & & 0.11 & 0.16 & \\
\hline 'actual' & & & 15.30 & 12.70 & \\
\hline \multirow[t]{5}{*}{$(2654 \mathrm{~m})$} & M3 & 1 & 13.35 & 9.11 & 0.69 \\
\hline & & $?$ & 15.10 & 10.77 & 0.63 \\
\hline & & 8 & 14.11 & 9.48 & 0.65 \\
\hline & & 10 & 14.55 & 9.88 & 0.68 \\
\hline & & 12 & 14.96 & 10.49 & 0.65 \\
\hline mean & & & 14.41 & 9.95 & 0.66 \\
\hline range/2 & & & 0.88 & 0.83 & \\
\hline & & & 0.71 & 0.69 & \\
\hline 'actual' & & & 16.60 & 11.20 & \\
\hline \multirow[t]{4}{*}{$(2447 \mathrm{~m})$} & M4 & 6 & 13.80 & 9.46 & 0.69 \\
\hline & & 9 & 14.71 & 10.64 & 0.65 \\
\hline & & 10 & 14.19 & 10.09 & 0.66 \\
\hline & & 12 & 13.86 & 9.55 & 0.67 \\
\hline mean & & & 14.14 & 9.94 & 0.67 \\
\hline range/2 & & & 0.46 & 0.59 & \\
\hline SD & & & 0.42 & 0.55 & \\
\hline 'actual' & & & 16.60 & 11.20 & \\
\hline \multirow[t]{5}{*}{$(1006 \mathrm{~m})$} & M5 & 1 & 13.66 & 9.30 & 0.69 \\
\hline & & 3 & 14.31 & 9.12 & 0.74 \\
\hline & & 4 & 14.95 & 10.50 & 0.71 \\
\hline & & 5 & 14.35 & 9.91 & 0.69 \\
\hline & & 11 & 15.56 & 11.28 & 0.64 \\
\hline mean & & & 14.57 & 10.02 & 0.69 \\
\hline range/2 & & & 0.95 & 1.08 & \\
\hline SD & & & 0.72 & 0.89 & \\
\hline 'actual' & & & 15.70 & 10.20 & \\
\hline
\end{tabular}

\begin{tabular}{lcrrrr}
\hline & Core & Depth $(\mathrm{cm})$ & $\mathrm{SST}_{\text {warm }}$ & SST $_{\text {cold }}$ & Comm. \\
\hline & & & & & \\
& & & & & \\
& $\mathrm{V} 1$ & $2.0-3.0$ & 27.18 & 22.49 & 0.95 \\
& & $3.0-4.0$ & 25.15 & 22.02 & 0.97 \\
& & $4.0-5.0$ & 25.58 & 22.99 & 0.96 \\
& $5.0-6.0$ & 26.63 & 22.46 & 0.95 \\
& & $6.0-7.0$ & 25.46 & 21.88 & 0.95 \\
mean & $8.0-9.0$ & 24.28 & 21.04 & 0.95 \\
range/2 & $9.0-10.0$ & 25.66 & 22.01 & 0.88 \\
SD & $10.0-11.0$ & 24.41 & 19.23 & 0.96 \\
'actual' & & 25.54 & 21.77 & 0.95 \\
& & & 1.45 & 1.88 & \\
& & & 0.99 & 1.17 & \\
& & & 24.10 & 21.70 &
\end{tabular}

$$
(4365 \mathrm{~m})
$$

V2

$2.0-4.0$
$4.0-6.0$
$6.0-8.0$
$8.0-10.0$

$\begin{array}{rrr}15.35 & 11.15 & 0.76 \\ 15.63 & 10.90 & 0.73 \\ 15.51 & 10.55 & 0.80 \\ 14.69 & 10.12 & 0.74 \\ \mathbf{1 5 . 3 0} & \mathbf{1 0 . 6 8} & \mathbf{0 . 7 6} \\ 0.47 & 0.52 & \\ 0.42 & 0.45 & \\ 16.80 & \mathbf{1 3 . 1 0} & \end{array}$

$\begin{array}{lrrr}\text { mean } & \mathbf{1 5 . 3 0} & \mathbf{1 0 . 6 8} & \mathbf{0 . 7 6} \\ \text { range/2 } & 0.47 & 0.52 & \\ \text { SD } & 0.42 & 0.45 & \\ \text { 'actual' } & \mathbf{1 6 . 8 0} & \mathbf{1 3 . 1 0} & \end{array}$

\begin{tabular}{|c|c|c|c|c|c|}
\hline \multirow[t]{7}{*}{$(4790 \mathrm{~m})$} & V3 & $1.0-2.0$ & 25.51 & 20.28 & 0.96 \\
\hline & & $2.0-3.0$ & 26.65 & 20.27 & 0.97 \\
\hline & & $3.0-4.0$ & 25.71 & 19.59 & 0.97 \\
\hline & & $4.0-5.0$ & 26.12 & 19.59 & 0.96 \\
\hline & & $5.0-6.0$ & 26.43 & 19.58 & 0.96 \\
\hline & & $7.0-9.0$ & 25.82 & 20.69 & 0.96 \\
\hline & & $9.0-11.0$ & 26.60 & 20.58 & 0.96 \\
\hline mean & & & 26.12 & 20.08 & 0.96 \\
\hline range/2 & & & 0.57 & 0.56 & \\
\hline SD & & & 0.45 & 0.49 & \\
\hline
\end{tabular}

Table 6A. Results of F20 TFA of core-top samples from sites M1-5.

\begin{tabular}{|c|c|c|c|c|c|c|c|}
\hline \multirow[b]{2}{*}{ Core } & \multicolumn{3}{|c|}{ Precision } & \multicolumn{4}{|c|}{ Accuracy } \\
\hline & $\begin{array}{l}\mathrm{SST}_{\text {warm }} \\
\text { range/2 }\end{array}$ & SD & $\begin{array}{l}\mathrm{SST}_{\text {cold }} \\
\text { range } / 2\end{array}$ & SD & $\mathrm{SST}_{\text {warm }}$ & $\mathrm{SST}_{\text {cold }}$ & Comm. \\
\hline M1 & 0.69 & 0.58 & 0.42 & 0.49 & -1.25 & -0.48 & 0.75 \\
\hline M2 & 0.14 & 0.11 & 0.2 & 0.16 & -1.28 & -3.14 & 0.71 \\
\hline M3 & 0.88 & 0.71 & 0.83 & 0.69 & -2.19 & -1.25 & 0.66 \\
\hline M4 & 0.46 & 0.42 & 0.59 & 0.55 & -2.46 & -1.26 & 0.67 \\
\hline M5 & 0.95 & 0.72 & 1.08 & 0.89 & -1.13 & -0.18 & 0.69 \\
\hline $\min$. & 0.14 & & 0.2 & & -2.46 & -3.14 & \\
\hline $\max$ & 0.95 & & 1.08 & & -1.13 & -0.18 & \\
\hline
\end{tabular}

\section{mean \\ range $/ 2$ \\ SD \\ 'actual'}

$(4847 \mathrm{~m})$

mean

range $/ 2$

SD

'actual'

$(4938 \mathrm{~m}) \quad \mathrm{V} 6$

mean

range/2

SD

'actual'
$1.0-2.0$

$2.0-3.0$

$3.0-4.0$

$5.0-6.0$

6.0-7.0

7.0-8.0

8.0-9.0

$9.0-10.0$

0.45
22.50

15.74

14.33

14.12

16.27

14.18

14.98

15.49

15.14

15.03

1.08

0.78

15.00

$$
\begin{aligned}
& 1.0-2.0 \\
& 2.0-3.0 \\
& 3.0-4.0 \\
& 4.0-5.0
\end{aligned}
$$

15.14
14.98
13.66
14.58
$\mathbf{1 4 . 5 9}$
0.74

0.74

0.66

18.20

$1.0-2.0$
$2.0-3.0$
$3.0-4.0$
$4.0-5.0$

25.28

25.86

26.19

26.58

25.98

0.65

0.55

23.30
0.69

0.81

0.73

0.83

0.79

0.81

0.84

0.80

0.79

10.34

1.39

0.82

12.80

$10.61 \quad 0.75$

$10.53 \quad 0.72$

$\begin{array}{ll}9.45 & 0.85\end{array}$

$10.99 \quad 0.71$

$10.40 \quad 0.76$

0.77

0.66
13.10

13.10

18.28
18.33
18.23
18.55
$\mathbf{1 8 . 3 5}$
0.16
0.14
$\mathbf{1 8 . 6 0}$

0.94

0.96

0.95

0.96

0.95

Table 6B. Comparison of multi-core F20 SST estimates with 'actual' SST at sites M1-5.

Table 7A. Results of F20 TFA of down-core samples from sites V1-6. 


\begin{tabular}{|c|c|c|c|c|c|c|c|}
\hline \multirow[b]{2}{*}{ Core } & \multicolumn{3}{|c|}{ Precision } & \multicolumn{4}{|c|}{ Accuracy } \\
\hline & $\begin{array}{l}\mathrm{SST}_{\text {warm }} \\
\text { range/2 }\end{array}$ & SD & $\begin{array}{l}\mathrm{SST}_{\text {cold }} \\
\text { range/2 }\end{array}$ & SD & $S T_{\text {warm }}$ & $\mathrm{SST}_{\text {cold }}$ & Comm. \\
\hline V1 & 1.45 & 0.99 & 1.88 & 1.17 & 1.44 & 0.07 & 0.95 \\
\hline V2 & 0.47 & 0.42 & 0.52 & 0.45 & 1.5 & -2.42 & 0.76 \\
\hline V3 & 0.57 & 0.45 & 0.56 & 0.49 & 3.62 & 0.32 & 0.96 \\
\hline V4 & 1.08 & 0.78 & 1.39 & 0.82 & 0.03 & -2.46 & 0.79 \\
\hline V5 & 0.74 & 0.66 & 0.77 & 0.66 & -3.61 & -2.7 & 0.76 \\
\hline V6 & 0.65 & 0.55 & 0.16 & 0.14 & 2.68 & -0.25 & 0.95 \\
\hline $\min$. & 0.47 & & 0.16 & & -3.61 & -2.7 & \\
\hline $\max$ & 1.45 & & 1.88 & & 3.62 & 0.32 & \\
\hline
\end{tabular}

Table 7B. Comparison of down-core F20 SST estimates with 'actual' SST at sites V1-V6.

compared in Table 6B. Here the minimum range of the $\mathrm{SST}_{\text {warm }}$ estimates is $\pm 0.14^{\circ} \mathrm{C}$ and the maximum $\pm 0.95^{\circ} \mathrm{C}$; for $S S T_{\text {cold }}$ the comparable figures are $\pm 0.20^{\circ} \mathrm{C}$ and $1.08^{\circ} \mathrm{C}$ respectively. Relative to present-day sea-surface temperatures the $\mathrm{SST}_{\text {warm }}$ estimates range from an underestimate of $-2.46^{\circ} \mathrm{C}$ to an underestimate of $-1.13^{\circ} \mathrm{C}$, and the $\mathrm{SST}_{\text {cold }}$ estimates from an underestimate of $-3.14^{\circ} \mathrm{C}$ to an underestimate of $-0.18^{\circ} \mathrm{C}$. Here again the variation in accuracy is larger than the variation in precision, and all SSTs are underestimated. It should be noted that the communalities for these samples are somewhat less than 0.8 (see above), but high communalities in the intra-sample set are associated with even higher inaccuracies. Once again only mean SST estimates are compared with the present-day seasurface temperatures.

\begin{tabular}{|c|c|c|c|c|c|c|c|c|c|}
\hline & \multirow[b]{2}{*}{ Core } & \multirow[b]{2}{*}{$\begin{array}{l}\text { Depth } \\
\text { (cm) }\end{array}$} & \multicolumn{3}{|c|}{ TFA } & \multicolumn{2}{|c|}{ Actual } & \multicolumn{2}{|c|}{ Accuracy } \\
\hline & & & $\mathrm{hSST}_{\mathrm{warm}}$ & $\mathrm{SST}_{\text {cold }}$ & Comm. & $\mathbf{S S T}_{\text {warat }}$ & $\mathrm{SST}_{\text {cold }}$ & $\mathrm{SST}_{\text {warm }}$ & $S S T_{\text {cold }}$ \\
\hline$(4830 \mathrm{~m})$ & $\mathrm{T} 1$ & $0-2$ & 24.25 & 17.72 & 0.88 & 19.60 & 16.20 & 4.65 & 1.52 \\
\hline$(4820 \mathrm{~m})$ & $\mathrm{T} 2$ & $2-4$ & 24.50 & 17.61 & 0.91 & 20.00 & 16.90 & 4.50 & 0.71 \\
\hline$(5070 \mathrm{~m})$ & T3 & $0-2$ & 22.16 & 16.33 & 0.82 & 20.60 & 15.30 & 1.56 & 1.03 \\
\hline
\end{tabular}

Table 8. Comparison of supra-turbidite F20 SST estimates with 'actual' SST at sites T1-3.

Our down-core variability results are summarized in Table $7 \mathrm{~A}$, and the precision and accuracy of these estimates are compared in Table 7B. Here the minimum range of the $\mathrm{SST}_{\mathrm{warm}}$ estimates is $\pm 0.47^{\circ} \mathrm{C}$ and the maximum $\pm 1.45^{\circ} \mathrm{C}$; for $\mathrm{SST}_{\text {cold }}$ the comparable figures are $\pm 0.16^{\circ} \mathrm{C}$ and $\pm 1.88^{\circ} \mathrm{C}$ respectively. Relative to present-day sea-surface temperatures in the same $1^{\circ}$ latitude/longitude square the $\mathrm{SST}_{\text {warm }}$ estimates range from an underestimate of $-3.61^{\circ} \mathrm{C}$ to an overestimate of $+3.62^{\circ} \mathrm{C}$, and the $\mathrm{SST}_{\text {cold }}$ estimate from an underestimate of $-2.70^{\circ} \mathrm{C}$ to an overestimate of $+0.32^{\circ} \mathrm{C}$. Note that whilst the variability in precision of the estimates is larger, between the four to eight down-core samples, than between the two intra-samples taken from the same sites, the accuracy of the estimates based on the means of these estimates is virtually identical.

Finally, in Table 8 we have made a comparison between the
$\mathrm{SST}_{\text {warm }}$ and $\mathrm{SST}_{\text {cold }}$ estimates, based on the three supraturbidite samples (in which downward bioturbation into earlier Holocene sediments is precluded), with the present-day seasurface temperatures in the relevant $1^{\circ}$ latitude/longitude squares. In these cases the $\mathrm{SST}_{\text {warm }}$ estimates overestimate present-day temperatures by $+1.56^{\circ} \mathrm{C}$ to $+4.65^{\circ} \mathrm{C}$, and the $\mathrm{SST}_{\text {cold }}$ estimates overestimate present-day temperatures by $+0.71^{\circ} \mathrm{C}$ to $+1.52^{\circ} \mathrm{C}$.

\section{CONCLUSIONS}

1. The results presented and discussed above, suggest (a) that the ranges of variation in estimates of SST obtained from sub-samples (intra-sample), multiple samples (inter-sample) and samples from the top $10 \mathrm{~cm}$ (down-core) of deep-sea cores are essentially indistinguishable, and (b) that the primary limitation on the precision of these estimates is the statistical counting error inherent in making estimates of the percentage species composition of planktonic foraminiferal assemblages on a count of 300 specimens.

2. The (in)accuracy of the estimates based on the F20 transfer function in the $\mathrm{NE}$ Atlantic can rise as high as an overestimate of $+3.62^{\circ} \mathrm{C}\left(+4.65^{\circ} \mathrm{C}\right.$ on a supra-turbidite sample) or an underestimate of $-3.61^{\circ} \mathrm{C}$. These limits of $\pm 3.62^{\circ} \mathrm{C}$ (range $7.23^{\circ} \mathrm{C}$ ) are considerable wider than the accuracy limits of $\pm 1.02^{\circ} \mathrm{C}$ (range $2.04^{\circ} \mathrm{C}$ ) assessed for $\mathrm{F} 20$ $\mathrm{SST}_{\text {warm }}$ estimates by Molfino et al. (1982). These results suggest there is a continuing need for improved methods for deriving proxy temperature data from planktonic foraminiferal assemblages in order to meet the needs of numerical modellers of past climates.

\section{ACKNOWLEDGEMENTS}

We are most grateful to Dr Colin Summerhayes, Dr Phil Weaver and Dr Andrew Gooday (Multi-corer core-top samples) for the provision of facilities, assistance and access to samples at the Institute of Oceanographic Sciences Deacon Laboratory (Wormley), and to Dr Barbara Molfino, of the LamontDoherty Geological Observatory of Columbia University (New York), for the provision of the Fortran code for the F20 TFA and general advice. This study was supported by NERC Research Grant GR3/8270'A'.

\section{Manuscript received January 1995 \\ Manuscript accepted October 1995}

\section{REFERENCES}

Gooday, A. J. \& Lambshead, P. J. D. 1989. Influence of seasonally deposited phytodetritus on benthic foraminiferal populations in the bathyal northeast Atlantic: the species response. Marine Ecology Progress Series, 58: 53-67.

Imbrie, J. \& Kipp, N. G. 1971. A new micropaleontological method for quantitative paleoclimatology: application to a late Pleistocene Caribbean core. In Turekian, K. K. (Ed.) The Late Cenozoic Glacial Ages. Yale University Press, New Haven, 71-181.

Imbric, J., van Donk, J. \& Kipp, N. G. 1973. Paleoclimatic investigation of a late Pleistocene Caribbean deep-sea core: comparison of isotopic and faunal methods. Quaternary Research, 3: 10-38.

Kipp, N. G. 1976. New transfer function for estimating past sea-surface conditions from sea-bed distribution of planktonic foraminiferal assemblages in the North Atlantic. In Cline, R. M. \& Hays, J. D. 
(Eds), Investigation of Late Quaternary Paleoceanography and Paleoclimatology. Memoir of the Geological Society of America, 145: 3-41.

Levitus, S. 1982. Climatological Atlas of the World Ocean. NOAA Professional Paper, 13: 1-173. U.S.Government Printing Office.
Molfino, B., Kipp, N. G. \& Morley, J. J. 1982. Comparison of foraminiferal, Coccolithophorid and Radiolarian paleotemperature equations: assemblage coherencey and estimate concordancy. Quaternary Research, 17: 279-313.

Prell, W. L. 1985. Technical Report TR025, Department of Energy, Washington, DC, $1-60$ 